\title{
们炭ピッチ系炭素緎維 ‥-ピッチ系高強度化へのアプローチ
}

\author{
佐藤 公隆*, 松末光昭**, 吉村 德男***
}

\section{1.はじめに}

炭素織維 (carbon fiber) は, 周知のように, アルミ ニウムより軽く，鉄より強いという特性をもち，先進複 合材料 (advanced composite materials) の強化用瀻維 として賞用されており，その出発原料によって PAN (polyacrylonitrile) 系, ピッチ系, レーヨン系などに分 粞される. PAN 手は, そのもつ高強度, 高弾件率の特 徵が生かされて航空機材料として，またスポーツ・レシ ャ一の素材として市場を占有しており，一力ピッチ系は すでに Amoco Performance Products 社 (長瀻維), 悲羽化学 (短織維) などによって工業化されて, 宇审や 一般産業資材などの用途で活権している.

この解説では，新しい技術思想を礎石とした石炭ビッ 千系峅素織維について，新日鐵グループ（新日本製鐵, 祈日鐵化学）での開発状況を中心に，高強度化を指向し た製造技術，得られた瀻維とその複合材料特性の位置つ けを朾碓にし，その成形加工製品，用途展開を紹介し， あわせて今後への期待と技術向上や市場開抔の課題につ いても述べる.

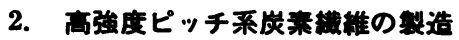

们菼タールを蒸留すると，装１に示すように数多くの 化学材料が得られる1. 石孷タールの主成分はペンゼン 核を含む単環および多摆芳香族炭化水素などで，現在， 400 種類以上の化合物が確認されているが，実際に製品 として利用されているものは 20 㮔類程度である2).

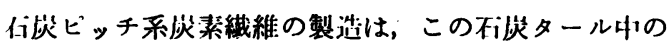

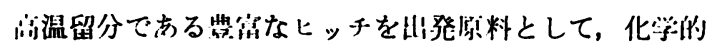

* Kimitaka SATO：新日本製鐵（株）新素材本業本 淿（100 果察都千代出区。手町 2-6-3）

** Mitsuaki MATsumoto：新日本製鐵 (株) 䉼釆 材事業本浰（671-11 姬路市公畑入富土町 1)

*** Tokuo YoshimURA：新日鐵化学 (侏) 觕品開発 センター（292 木更津市新港 15-1）
処理，ろ過，熱処理などの操作を通して，紡禾性にすぐ れたピッチに改質することからはじまり，押出紡系によ りピッチ絨維とし, さらに不融化処理, 炎化処理により 炭素緎維, 黒鉛化処理を経て黒鈆瀻維として製选され る3).

これらの製造工程のなかで，とくに离強度化を指向す る場合の技術的力点は,

（1）离度に精製された原料ピッチの製造，

(2) 緎維の軸方向および断面方向での黑鉛化性の個別 制御,

の 2 点であり, 以下, その技術の要点について述べる.

\section{1 高度精製メソフェースピッチの製造}

ピッチ系炭素絨維の製造にあたって, 紡糸用のピッチ は当然のことながら紡糸珄にすぐれているとともに良好 な織維特性を与えるものでなければならない，そのため には，つぎのような技術の棈築が必要である.

a. 低温紡系技術

b. 異物除去技術

これらの技術課題のうち，aのテーマに対しては「ビ ッチの水素化」，またbのテーマに対しては「ピッチの 精密ろ過」がそれぞれ有効である.これらの実験データ の一例として, 図 1 に水素化によるメンフェースピッチ の軟化点の低下効果を示す，これにより，紗系温度を低 くすることが可能であり, 紡糸が安定化するととすに, 緎維強度む大幅に向上する.

ピッチの精密ろ過については, 闾形翼物を $99 \%$ 以上 除去する新しい技法を導入することによってピッチの䊏

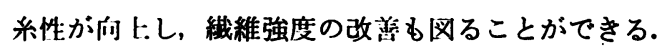

さらにピッチの熱改所ブロセスを綿密に条作解析す ることによって，特殊なブロせ、が侀発されており，ピ

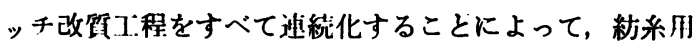

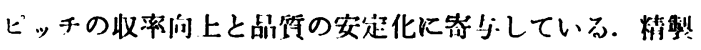
された原料ヒッチの特攸例を就 2 に示す.

\section{2 炭来縤䊒櫵造の制御}

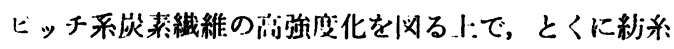




\section{表 1 石炭タール蒸留と留出油の組成}

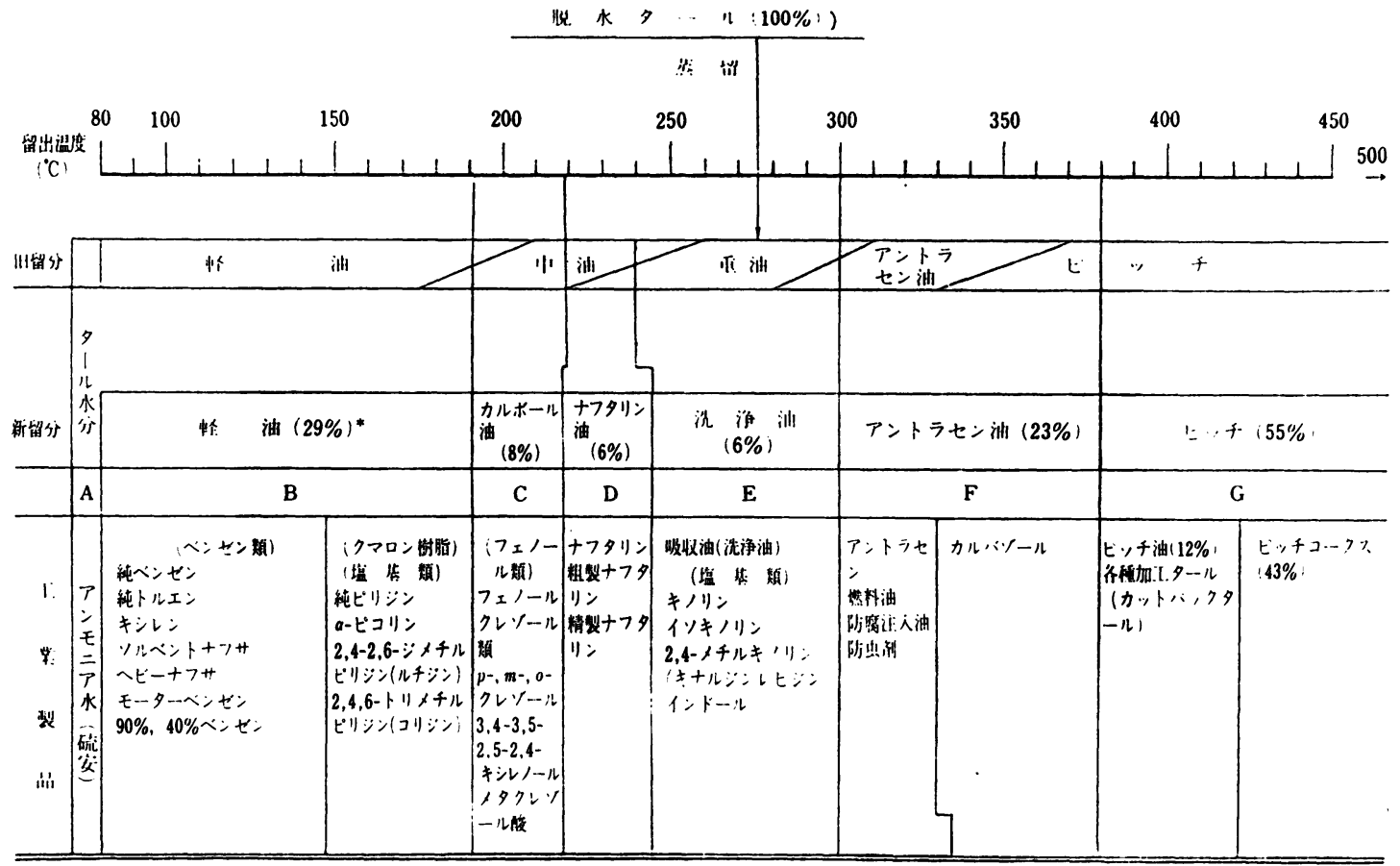

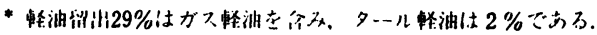

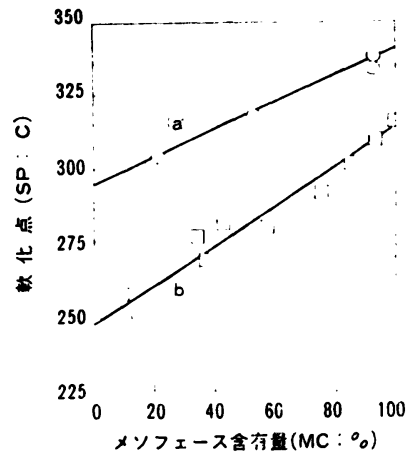

以 1 水素化処理によるメンフェースピッチの顿化 点低下効果（真空中 $430 \sim 450^{\circ} \mathrm{C}$ 坆処埋）

(a) 水素化処理前, (b) 水素化処耼後

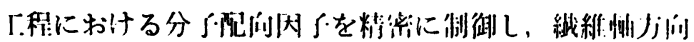

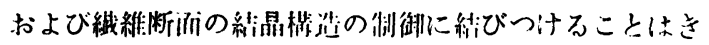
わめて車要なことである.

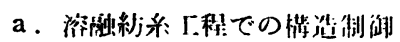

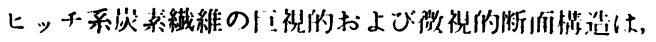

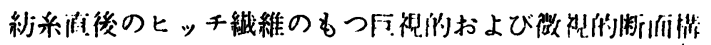

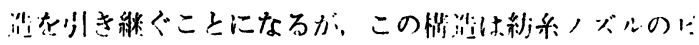

发 2 精製们荻タールビッチの特性:の一例

特 性:

特性值例

\begin{tabular}{|c|c|c|}
\hline 軟 化 䈍 & $\left({ }^{\circ} \mathrm{C}\right)$ & \\
\hline 回定获桌 & $(\%)$ & \\
\hline トルェン不渗分 & $(\%)$ & \\
\hline キノリン不溶分 & $(\%)$ & 疲 \\
\hline 尒 & $(\%)$ & 拉 \\
\hline
\end{tabular}

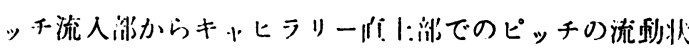

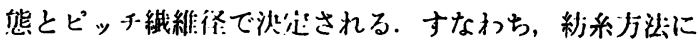

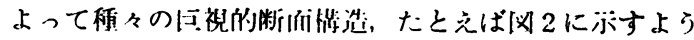

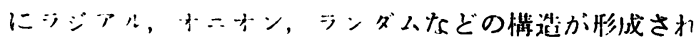
๘.

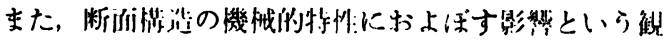

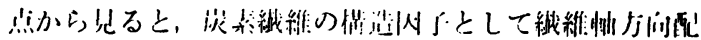

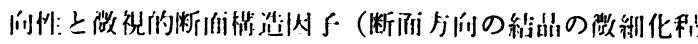

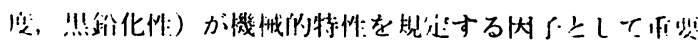

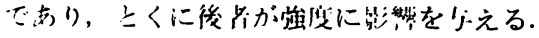

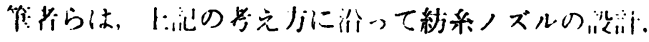

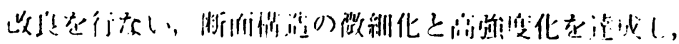




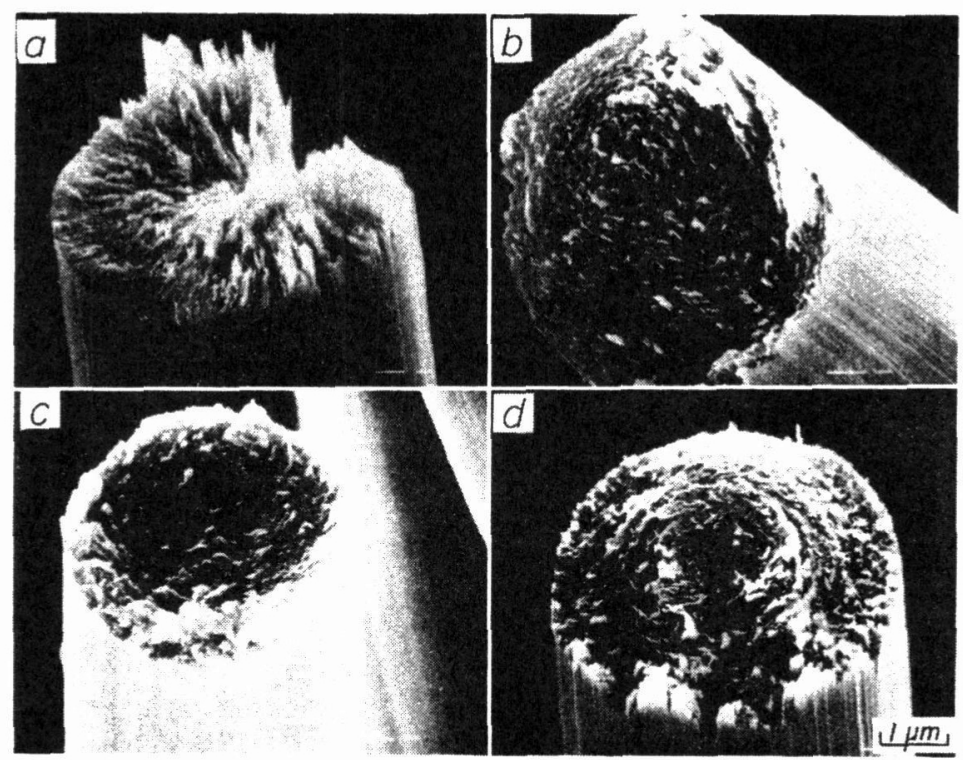

図2 石炭ピッチ系炭素繊維 $\left(2,500^{\circ} \mathrm{C}\right.$ 熱処理) の断面微細構造の走査型電 子顕微鏡像
(a)ラジアル,
(b) オニオン,
(c) ランダム,
(d) 擬似オニオン

表 3 新日鐵・石炭ピッチ系炭素㵶維のおもな特性例

\begin{tabular}{|c|c|c|c|c|c|c|c|c|c|c|}
\hline \multirow{2}{*}{\multicolumn{2}{|c|}{ おるな特性 }} & \multirow{2}{*}{\multicolumn{3}{|c|}{ 汎用タイプ }} & \multicolumn{6}{|c|}{ 高性能タイプ } \\
\hline & & & & & \multicolumn{3}{|c|}{ 標準タイプ } & \multicolumn{3}{|c|}{ 高強度タイプ } \\
\hline 性 & 単 位 & NG-P4 & NG-04C & NG-05G & NS-P5 & NS-20 & $\mathrm{NS}-40$ & NT-20 & $0 \quad$ NT -40 & NT-60 \\
\hline 重 & - & 1.4 & 1.65 & 1.60 & 1.4 & 1.95 & 2.07 & 1.95 & 2.07 & 2.15 \\
\hline 径 & $\mu \mathrm{m}$ & 15 & 13 & 13 & 13 & 10 & 10 & 10 & 10 & 10 \\
\hline 引張り強度 & $\mathrm{kgf} / \mathrm{mm}^{2}$ & 17 & $80-100$ & $80-100$ & 20 & $180-210$ & $240-270$ & $280-310$ & $330-360$ & $320-350$ \\
\hline ‘張り弾性率 & $\mathrm{tf} / \mathrm{mm}^{2}$ & 0.4 & 4.5 & 4.5 & 0.5 & 20 & 40 & 20 & 40 & 60 \\
\hline 度 & $\%$ & 5 & 2.1 & 2.0 & 4 & 1.0 & 0.65 & 1.45 & 0.85 & 0.55 \\
\hline 比抵 抗*1 & $\mu \Omega \mathrm{m}$ & & 90 & 31 & & 14.5 & 8.8 & 12.6 & 8.9 & 6.6 \\
\hline 熱*2 & $\mathrm{J} / \mathrm{g} \cdot \mathrm{K}$ & - & 1 & 1 & & 1 & 1 & 1 & 1 & 1 \\
\hline 熱 伀 導 率*1,2 & $\mathrm{J} / \mathrm{cm} \cdot \mathrm{s} \cdot \mathrm{K}$ & - & 0.02 & 0.05 & - & 0.05 & 0.5 & 0.1 & 0.3 & 0.8 \\
\hline 炭素含量 & wt $\%$ & $(>85)$ & $>94$ & $>99$ & $>88)$ & $>98$ & $>99$ & $>98$ & $>99$ & $>99$ \\
\hline
\end{tabular}

[注] *1 軸方向, ${ }^{* 2} 25^{\circ} \mathrm{C}$

\section{ランダム，オニホンなどの巨視的微視的满造を作り分け ている.}

b. 化学的反応による瀻維物性の改善

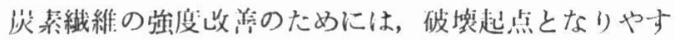

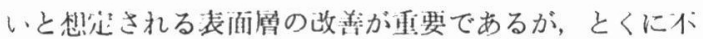
融化㸡の酸化処理反必が效果的であり，それに心じて伂 㴽も向上する.

\section{3. 織維およびその複合材料特性}

石湠ビッチ系炭素繊維について新日鐵グループを例に とり, 數段皆で得られているおもな特吽を表 3 に示す. これらの特性は近い将来さらに改善, 向上するものと期 待される. このうち, 汎用タイプのみ原料ピッチは光学 的等方性であるが，高性能タイプは光学的異方性 (メッ 


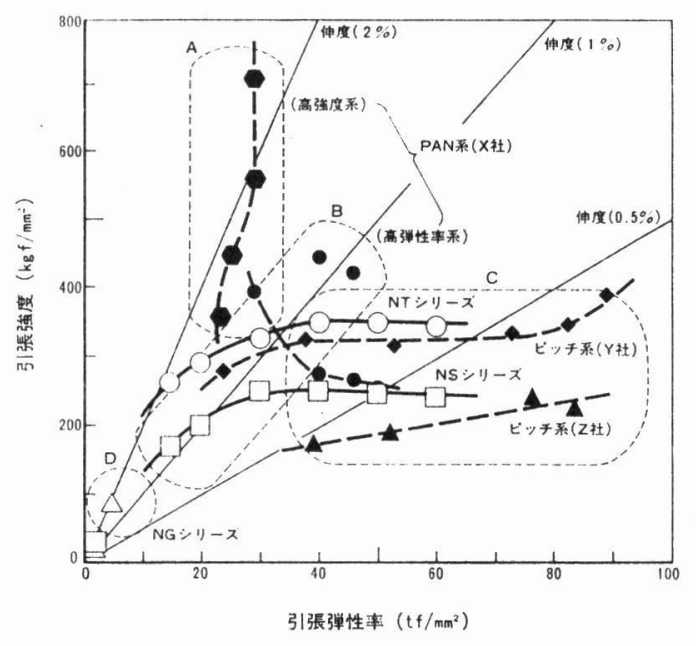

図 3 新日鐵·石炭ピッチ系炭素繊維 (NG, NS, NT 各シリーズ）と PAN 系, 他社ピッチ系の引 張り特性の傾向

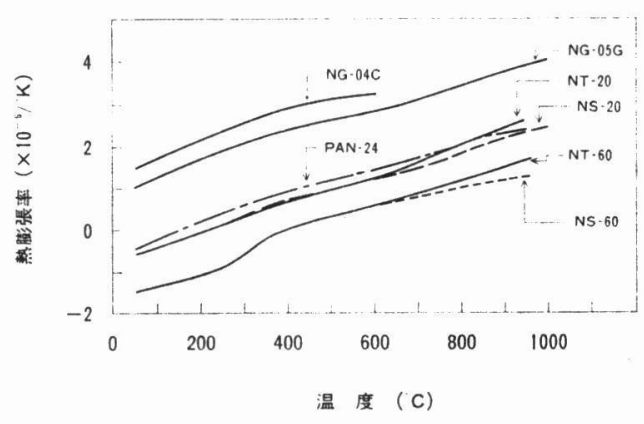

図 4 石炭ピッチ系炭素㵶維の熱膨張特性

フェース）ピッチを使用している.

\section{1 機械的特性}

この石炭ピッチ系炭素繊維の引張り特性を, 代表的な PAN 系および石油ピッチ系の場合と対比させて図 3 に 示す. 引張り強度 $350 \mathrm{kgf} / \mathrm{mm}^{2}$ (引張り弾性率 40 50 $\left.\mathrm{tf} / \mathrm{mm}^{2}\right)$ を達成しているが, この值はピッチ系炭素繊維 として世界的にトップレベルにある.

\section{2 熱的特 性}

熱膨張係数と温度との関係を図 4 に示す. とくに, 㷛 伝導率および熱膨張係数は, 㵶維の黒鉛化が進むにつれ て,すなわら高弾性率になるにつれて, 熱伝導率は大きく 熱膨張係数は小さくなる顕著を傾向を示しており,なか でも熱膨張係数は高弾性率系の場合, 比較的低温でマイ ケスの值をとっている.このよらな挙動は, 用途開発に あたって配慮すべき重要な因子で放り,たとえば C/C

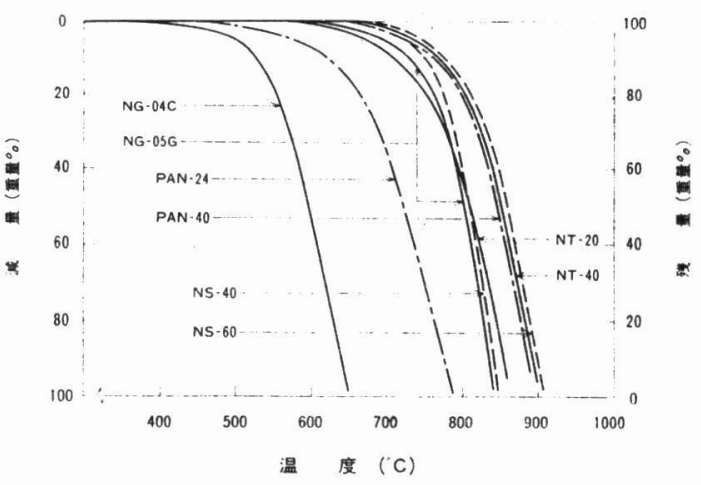

困 5 石炭ピッチ系炭素緎維の耐酸化特性 (空気中, $10^{\circ} \mathrm{C} / \mathrm{min}$ で昇温)

ソポジット（炭素纎維強化炭素複合材料）やCFRM（岸 素繊維強化金属) などの製造条件, さらには複合材料物 性に効果的な役割を果たすことが多い。

\section{3 電気的特性}

電気抵抗值は, 高弾性率系になるにつれて小さくな り, 電気伝導性がよくなる、その倾问は衣 3 に亦すとお りである. この現象を利用して種々の用途が検封されて いるが，さらに電気伝導性を必要とする場合には，後述 する金属被覆炭素緎維，さらには黒鉛層間化合物にも有 効である.

\section{4 耐酸化特性}

炭素纎維を含めて一般に炭素材料は, とくに高温時に 酸化消耗性がある. 石炭ピッチ系炭素㵶維について詊価 した結果を図 5 に示す.この結果から, 繊維の黒鉛化が 進むにつれて耐酸化性が向上する傾向があり，たとえば 沉用グレードでも黒鉛化処理した NG-05G や中弾性高 性能グレードの NT-20 クラスでも, PAN 系炭素㵶維 の弾性率 $24 \mathrm{tf} / \mathrm{mm}^{2}$ と比較してよりすぐれた挙動を亦 すことがわかる.

\section{5 複合材料特性}

機械的特性を評価した絬果を表 4 にボす，引張り特性 に対する発現率はいずれも $80 \%$ 以上と良好である.また 圧縮強度について，ピッチ系拈よび PAN 系を比較した ものを図 6 に示す.この図からこの石炭ピッチ系 (NT シリーズ）は圧縮強度において従来のピッチ系と PAN 系の中間程度まで向上していることがわかり，それに応 じてこの性質を生かせる新しい用途も拓かれるものと期 待される.

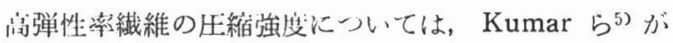
織維密度，䋐維微細满造モデルなどの観点から検部を行 ない, 絬晶子の微細化と絡み合い情造 (entangled struc- 
衣 4 石炭ピッチ系炭素繊維・エポキシ樹脂複合材料の特性例 $\left(V_{f}=60\right)$

\begin{tabular}{|c|c|c|c|c|c|c|c|}
\hline \multirow[b]{2}{*}{ 織維タイフ } & \multicolumn{2}{|c|}{$0^{\circ}$ 引張り } & \multicolumn{2}{|c|}{$0^{\circ}$ 曲 ゲ } & \multicolumn{2}{|c|}{$0^{\circ}$ 圧 縮 } & \multirow{2}{*}{$\begin{array}{c}\text { ILSS } \\
\left(\mathrm{kgf} / \mathrm{mm}^{2}\right)\end{array}$} \\
\hline & $\left(\mathrm{kgf} / \mathrm{mm}^{2}\right)$ & $\begin{array}{c}\text { 弾性率 } \\
\left(\mathrm{tf} / \mathrm{mm}^{2}\right)\end{array}$ & $\begin{array}{c}\text { 強 } \\
\left(\mathrm{kgf} / \mathrm{mm}^{2}\right)\end{array}$ & $\begin{array}{c}\text { 弾性率 } \\
\left(\mathrm{tf} / \mathrm{mm}^{2}\right)\end{array}$ & $\begin{array}{c}\text { 強 } \\
\left(\mathrm{kgf} / \mathrm{mm}^{2}\right)\end{array}$ & $\begin{array}{c}\text { 弾性率 } \\
\left(\mathrm{tf} / \mathrm{mm}^{2}\right)\end{array}$ & \\
\hline NT-15 & 153 & 10.5 & 131 & 7.6 & 82 & 11.4 & 9.7 \\
\hline $\mathrm{NT}-20$ & 138 & 9.8 & 156 & 10.2 & 71 & 10.4 & 10.2 \\
\hline NT -40 & 180 & 18.0 & 130 & 17.0 & 65 & 20.0 & 9.0 \\
\hline NT -50 & 160 & 24.0 & 110 & 19.0 & 55 & 22.0 & 8.5 \\
\hline NT-60 & 160 & 29.0 & 95 & 25.0 & 50 & 30.0 & 8.0 \\
\hline $\mathrm{NG}-04 \mathrm{C}$ & 50 & 2.7 & 76 & 2.8 & 6 & 3.2 & 7.7 \\
\hline
\end{tabular}

表 5 金属被覆ピッチ系炭素繊維の電気的特性の例

\begin{tabular}{|c|c|c|c|c|c|}
\hline \multirow{2}{*}{ 絾維グレード } & \multirow{2}{*}{ メッキの種類 } & \multicolumn{2}{|c|}{ メッキ厚 $(\mu \mathrm{m})$} & \multicolumn{2}{|c|}{ 比抵抗 $(\mu \Omega \cdot \mathrm{m})$} \\
\hline & & $\mathrm{Ni}$ & $\mathrm{Cu}$ & 原 系 & メッキ品 \\
\hline $\mathrm{NG}-04 \mathrm{C}$ & $\mathrm{Ni}-\mathrm{Cu}$ & 0.19 & 1.17 & 65.2 & $7.97 \times 10^{-2}$ \\
\hline NS-40 & $\mathrm{Ni}-\mathrm{Cu}$ & 0.21 & 1.07 & 12.7 & $5.64 \times 10^{-2}$ \\
\hline NS-60 & $\mathrm{Ni}$ & 0.26 & - & 7.44 & $9.28 \times 10^{-1}$ \\
\hline NS-60 & $\mathrm{Ni}-\mathrm{Cu}$ & 0.25 & 0.96 & 7.58 & $9.54 \times 10^{-2}$ \\
\hline
\end{tabular}

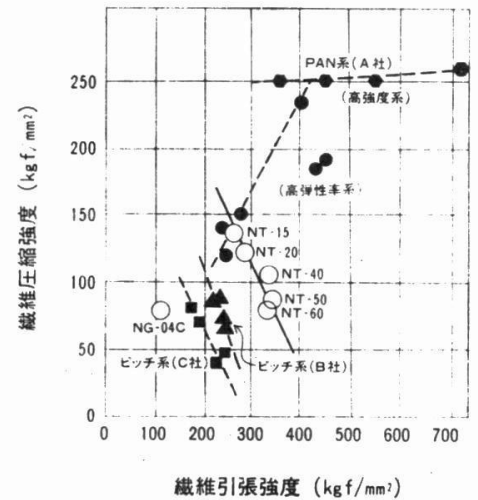

汹 6 イ谈ピッチ系炭素瀻維の圧縮強度特性と PAN 系, 他社ピッチ系との比較

ture), 折り而ねシート蓝造 (folded sheet structure)

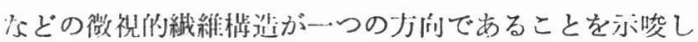
ている. ピッチ系炭素瀻維についても, 厓縮強度の向上 のみならず，さらに鬲強度化を目指す上においてもこの 微視的絬晶橧造の改並が今後の高性能化への重要な研究 料是であると芦えられる。

\section{4. 成形加工製品と用途展開}

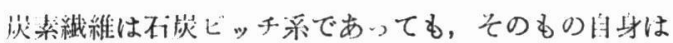

素材であり, 一般にはプラスチック，金属，セラミック などの強化補強用として複合材料化されて使用されるこ とが多い。ここでは，それぞれの製品化の状況について 簢戦にふる。

\section{1 一次加工製品}

一次加工製品としては，ペーパーフフェルトおよび組 紐, 活性炭素瀻維（この㵶維状活性炭は, 吸着速度が粒 状活性炭に比べて 10〜20 倍速く, しか子長緎維, チョ ップのほかフェルト, ペーパーなどの形状に成形加工で きる)，二軸抢よび三軸織物や立体織物，金属および樹 脂被覆炭素㵶維, さらにコンパウント゚, プリプレグなど が開発されている. 金属被覆したピッチ系炭素繊維の電 気的特性を表 5 に示す.

\section{2 用途開拓への展開}

岑素䋐維複合材料としては， ツトリックスがプラスチ ッ (CFRP, CFRTP), コンクリート (CFRC), 岑浆 (C/C コンポシット), 金属 (CFRM/MMC) およびセラ ミック (CFRC) などが知られているが, 石岑ヒッチ系炭 素㵶維についてもその特徵を生かしてそれぞれの複命材 料への用途開拓が進められている.

これらの複合材料のなかで, C/C コンボジットは驸 熱性にすぐれているなどいくつかの特徽を有することか ら関心のあるものの-・つで，その特性の一例を表 6 に亦 
素 $6 \mathrm{C} / \mathrm{C}$ コンポジットの特性の一例

\begin{tabular}{|c|c|c|}
\hline & タイプA & タイプ B \\
\hline 炭素織維の形態 & クロス積層 & UD (一力问) \\
\hline 紻維含有率（\%) & 57 & 50 \\
\hline 密度 $\left(\mathrm{g} / \mathrm{cm}^{3}\right)$ & 1.75 & 1.64 \\
\hline ’張り強度 $(\mathrm{MPa})$ & 190 & $340\left(0^{\circ} \mathrm{j}\right.$ 向 $)$ \\
\hline 曲げ強度（MPa） & 180 & 500 \\
\hline 曲げ弾性率（GPa） & 60 & 140 \\
\hline \multicolumn{3}{|l|}{ 衝撃強度 (ノッチ付き) } \\
\hline$\left(\mathrm{kg} \cdot \mathrm{cm} / \mathrm{cm}^{2}\right)$ & 27 & 94 \\
\hline 此熱 (J/g K) & 0.93 & 1.03 \\
\hline 熱伝導率 $(\mathrm{J} / \mathrm{cm} \mathrm{s} \mathrm{K})$ & $0.06(1)$ & 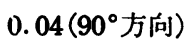 \\
\hline 熱膨張率 $\left(\times 10^{-6} \mathrm{~K}^{-1}\right)$ & $1.3(11) 9.8(\perp)$ & 0.7 (0 $0^{\circ}$ 方向 $)$ \\
\hline
\end{tabular}

（II）は積層方向，（上）は積層面に垂值方向を示す.

す. 今後， $\mathrm{C} / \mathrm{C}$ コンホジットは航空機のブレーキやロケ ットのノーズューンなどに限らず, メカニカルシールな どの部品など一般産業用材料として広く応用されること が期待されている.

CFRM む強い関心のある複合材料の一つであり, 航空 機や自動本の部品のほか, 種々の一般産業用材料として も有望な用途がいくつか見いだされている.この材料は とくに用途が明確になって仕梯が決まる要素が強いた め, ニーザーとの連携が今後とも不可火と考えられる.

\section{5. 今後の課題}

ピッチ系炭素絨維恃，化学反応，紡系技術，㸗温灯技 術などにより集大成される総合技術の結晶である4-8). ピッチ系炭素織維に課せられた今後の課題はつぎのよう に奖約される。

a. 高強度化

b. 王縮強度の改谣

c . 界面技術の確立 d. コスト低減

e. 標準化および見格化

これらの各課面に対するさらなる棁明は少略するが， とくに課趋 a , b は 1989 年度からスタートする新しい 次世代産業技術研究開発国家プロシェェク「超耐環境性 先進材料」の提萿9 の中にも，ピッ千系炭素瀻維に対す る課題として，“織維径の極紼化”とともに盛り込まれ ていることを付需しておきたい．

そしてこのピッチ系荻素䄉維は，一部はPAN 系と競 命，共通する用途分野はあるにしても，新しい材料とし て今後とも幅広く用途，市場を開抔していくべき材料と 期待している.

このピッチ系炎素絨維には，技術的にも，事業の上で る難しさがあるるのの, 大きな拡がり，魔力ともい方る 兔力，そして永遠のロマンがあると筆者には思えてなら ないことを記して本稿の結びとしたい。

\section{参考文献}

1）吉田 尚：これからの石炭化学工業, 技報堂, 米 京 (1977), p. 20.

2) 佐藤公隆：化学経済， 34，11 (1987)， 28.

3）たと六ば，有田静児，山田康弘，今村 健，柴田 昌男: 通商産業省工業技術院昭和62年度特別研究 報告集，日本産業技術振興協会（1988.3），p.142.

4) T. Hamada, T. Nishida, Y. Sajiki, M. Matsumoto \& M. Endo : J. Mater. Res., 2, 6(1987), 850.

5) S. Kumar, W.W. Adams \& T.E. Helminiak : J. Rein. Plast. Compo., 7 (1988), 108.

6) 富岡紀夫：鉄と鋼，75， No. 9 (1989), 印刷中.

7) T. Hamada, T. Nishida, M. Furuyama \& T. Tomioka : Carbon, 26, 6 (1988), 837.

8) T. Hamada, Y. Sajiki, M. Furuyama, T. Tomioka \& M. Endo : J. Mater. Res., 印刷中.

9) 超耐環境性先進材料調査委員会編：超耐環境性先 進材料開発の見状と今後の課题, 日本産業技術振 興協会，次世代金属・複合杵料研究開発協会 (1988.9), p.427. 